\title{
ESTIMATING PARTICLE CONCENTRATION \\ IN NATURAL WATER \\ BY SPECKLE CONTRAST
}

Dan CHICEA *

* "Lucian Blaga" University of Sibiu, Faculty of Sciences, Dr. Ion Raţiu Street 5-7, Sibiu, Sibiu County, Romania, RO-550012,dan.chicea@ulbsibiu.ro

KEYWORDS: Coherent Light Scattering, Suspension, Particle Concentration, Speckle contrast.

\section{ABSTRACT}

A coherent light scattering experiment was carried out on an aqueous clay suspension with an extended range of concentrations. The far field speckle was recorded as a video recording in an unconventional manner using a charged coupled device. A computer code for image processing, written for this purpose, was used to compute the average far field contrast. The variation of average contrast with particle concentration was analysed, and a possible fast procedure for assessing the particle concentration over an extended concentration range was suggested.

ZUSAMMENFASSUNG: Abschätzung der Partikelkonzentration im natürlichen Wasser durch Tupfergegensatz.

Ein koharentes Lichtstreuung Experiment im wasserigen Kleiflussigkeit, mit eine Konzentration das sich uber einen grossen Aktionsradius erstreckt, wird durchgefuhrt. Das erweiterte Bereich Tupfer wurde als Film ausgezeichnet in einem unkonventionellen Art und Weise mit Hilfe der "charged coupled" Geraet. Auch einen speziellen PC Kode fur Bildbearbeitung, geschrieben fur dieses Experiment, wurde benutzt beim Berechnung des erweiterte Bereich Gegensatz. Die Veränderung der mittleren Gegensatz mit dem Partikelkonzentrazion war beobachtet und einen moglichen Ablauf fur das Festsetzen des Partikelkonzentrazion uber einen erweiteren Bereich wird vorgeschlagen.

REZUMAT: Estimarea concentraţiei de particule în apa naturală prin contrastul imaginii de interferență.

A fost efectuat un experiment de împrăştiere a luminii pe suspensie de lut, având o concentraţie care se întinde pe un interval extins. Imaginea de interferență de câmp îndepărtat a fost înregistrată ca film, folosind un dispozitiv de tip „charged coupled”. Contrastul imaginii a fost calculat cu un program scris în acest scop. A fost analizată variaţia contrastului mediu cu concentraţia de particule şi este sugerat un procedeu rapid de estimare a concentraţiei pe un interval extins. 


\section{INTRODUCTION}

Natural water contains particles in suspension with different proveniences. The particles in suspension are the cause of water opacity. This physical property of natural water is named turbidity (Waterwatch Australia, 2002). Suspended particles can be clay, sand, silt, algae, plankton, micro-organisms and other substances (National Soil Survey Handbook, 2006). Suspended particles absorb visible light and the absorbed energy causes the increase of the particles temperature. Heat is transferred to the water that contains the particles, therefore water temperature increases faster in turbid water than it does in clear water under the same incident light intensity. Gumpinger et al. (2010), state that "water temperature is considered one of the most essential regulating parameters in aquatic ecosystems". Water temperature is also one of the most important ecological parameters of aquatic and semi-aquatic organisms (Fulga and Kiseliova, 2006; Blănaru, 2008; Zubcov et al., 2008; Salem, 2011). Moreover, because of the intensive interrelations with other physical and chemical parameters, water temperature has a high indicative value when considering the general condition of an aquatic ecosystem (Coman and Sandu, 2009; Gumpinger et al., 2010).

Turbidity is often used as an indicator of the total amount of material suspended in water, but is not a measure of the concentration or size of the particles in water. Nevertheless, knowing the size and the type of the suspended particles is important also because the fine particles suspended in water can carry bacteria, excess nutrients and toxic materials, which might be a hazard for drinking water and not only.

Optical procedures for assessing the amount of particles in suspension in water are appealing as they are fast and do not require physical or chemical processing of the samples. When coherent light crosses a medium with scattering centres (SC), an un-uniformly illuminated image is obtained, currently named speckled image, with a statistic distribution of the intensity over the interference field. The speckled image appears as a result of the interference of the wavelets scattered by the SCs, each wavelet having a different phase and amplitude in each location of the interference field. The image changes in time as a consequence of the SCs complex movement of sedimentation and Brownian motion, giving the aspect of "boiling speckles" (Goodman, 1984; Briers, 2001).

The speckled image can be observed either in free space, and is named objective speckle, or on the image plane of a diffuse object illuminated by a coherent source, and it is named subjective speckle (Goodman, 1984). The review paper (Briers, 2001) classifies the two types of speckled images as far field speckle and image speckle. In this work the objective speckle, respectively far field speckle is considered.

The speckle parameters like size, contrast, intensity and polarization carry information on the scattering media. Dynamic speckle analysis has become a current method to characterize the dynamic behaviour of scattering medium such as flow, sediment and Brownian motion. The motion of the speckle field was analyzed by correlometric methods (Aizu and Asakura, 1991; Boas and Yodh, 1997; Fedosov and Tuchin, 2001) or by laser speckle contrast analysis (Briers et al., 1999; Zimnyakov et al., 2002). The speckle size can be used to measure the roughness of a surface (da Costa and Ferrari, 1997; Lehmann, 1999; Berlasso et al., 2000) or to assess the thickness of a semi-transparent thin slab (Sadhwani et al., 1996). The above mentioned experiments use the backscattered speckle configuration. Giglio et al. (2001) and other papers report a different optical set-up to measure the correlation function in the near field, and to show the near-field speckle dependence on the particles size. The work reported by Piederrière et al. (2004a, b) and Chicea (2007a) used a transmission optical set-up to measure the far field parameters like contrast and speckle size. The transmission type of setup was used in the work reported in the present paper as well. 
In this work, a simple physical experimental procedure that uses coherent light scattering on a clay suspension and a charged coupled device (CCD hereafter) to record the scattered far field, assisted by a set of computer codes, that can be used to assess the average concentration of clay particles suspended in water, over a wide range, from $1.54 \mathrm{~g} / 1$ to $6.6 \mathrm{~g} / \mathrm{l}$ is presented in detail. The experimental procedure, the computer codes and the procedure of using them to assess the clay particle concentration are presented in detail in the next sections.

\section{MATERIALS AND METHODS}

Clay taken from the bottom of the Trinkbach River that crosses Sibiu locality (Transylvania, Romania) was taken and diluted in water, allowed to sediment for 24 hours and the water was discarded to remove the organic suspension. The sediment was dried, weighed and then was mixed with deionised water to produce samples of clay particles suspension with different concentrations.

Prior to starting the light scattering image experiment, a diluted suspension was subject of a Dynamic Light Scattering experiment using a modified procedure extensively described (Chicea, 2007a; 2012a, b, c; Chicea et al., 2012). The average diameter of the clay particles was found to be $0.6 \mu \mathrm{m}$. The experiment scheme is presented in figure number 1 .

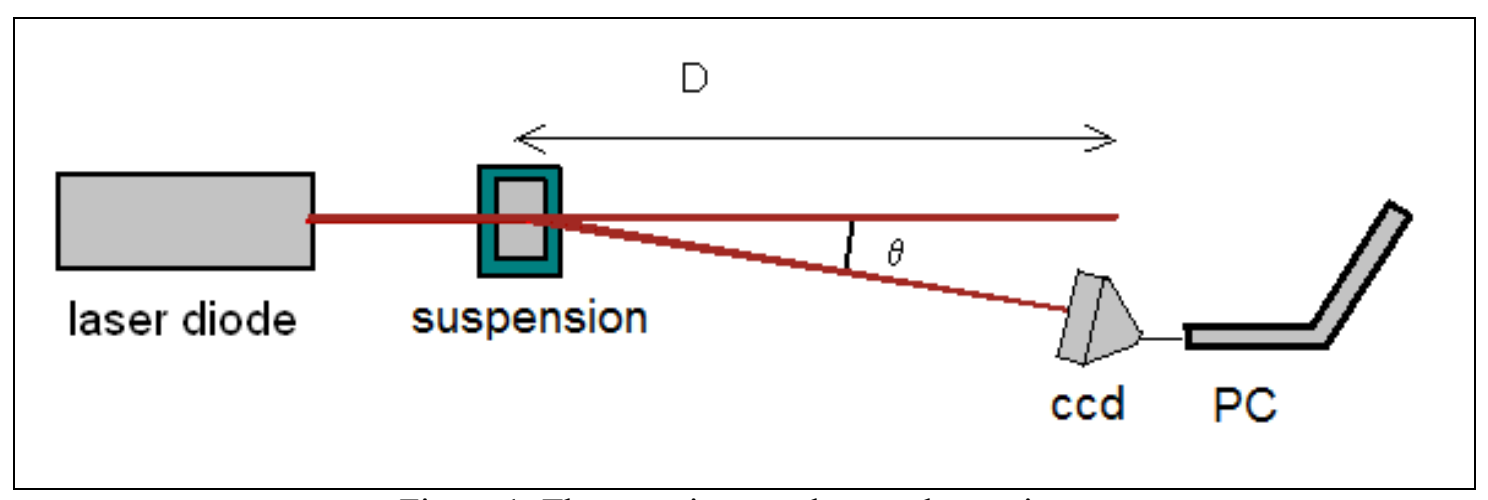

Figure 1: The experiment scheme, above view.

The coherent light source was a laser diode that had a wavelength of $633 \mathrm{~nm}$ and a constant power of $20 \mathrm{~mW}$. No polarizer was placed between the laser and the glass cuvette, which was $12 \mathrm{~mm}$ thick. D was $0.165 \mathrm{~m}$ and the Philips SPC900NC CCD camera was placed $0.01 \mathrm{~m}$ apart from the beam making the measurement angle to be $3^{\circ} 28^{\prime} 5.6^{\prime \prime}$. The optical system of the camera was removed, therefore the recorded images are the direct interference on the CCD detection matrix; so the far field speckle was recorded. The resolution was 640x480 pixels, the frame rate was 10 frames per second (fps) and the colour depth was 16 bits. More details on the optical setup have extensively been presented (Chicea, 2007a, b; 2013). A frame containing the far field speckle taken from the movie, having a concentration of $3.53 \mathrm{~g} / 1$, is presented in figure number 2 .

The average speckle size is currently calculated as the normalized auto covariance function of the intensity speckle pattern got in the observation plane (Piederrière et al., 2004a, b). In this paper, a different approach is proposed to relate the particle concentration with one of the first order far field statistics parameter. The average contrast is calculated instead of the speckle size. 
The average contrast of the image, either acquired as a bitmap or extracted from the frames of the movie, is currently calculated (Goodman et al., 1984; Briers, 2001) as:

$$
K=\frac{\sqrt{\left\langle(I(i, j)-\langle I\rangle)^{2}\right\rangle}}{\langle I\rangle}
$$

In (1) $\mathrm{K}$ is a space contrast and not a time contrast, as it was pointed out by Nothdurft and Yao (2005) and by Chicea (2007b). In (1) the angular brackets stand for the average over the entire $640 \times 480$ pixels collection of intensity values for an image that is processed.

The movie was processed by a computer program written for this purpose. The program reads the movie, extracts frame by frame in a 640x480 array of intensity levels. We can note $I(i, j)=I(x i, y j)$ the intensity recorded by the cell $(i, j)$ of the CCD, hence by the pixel $(i, j)$ of the array of pixels the image consists of. Once the array of intensities is extracted for each frame, the contrast of each particular frame is calculated using (1). The collection of contrast values is averaged and is considered to be the contrast value for that particular movie, hence for that particular sample. The standard deviation for the collection of values computed for one sample is considered to be the relative error in assessing the contrast for that particular sample; therefore the error bars in figure number 3 are the standard deviations.

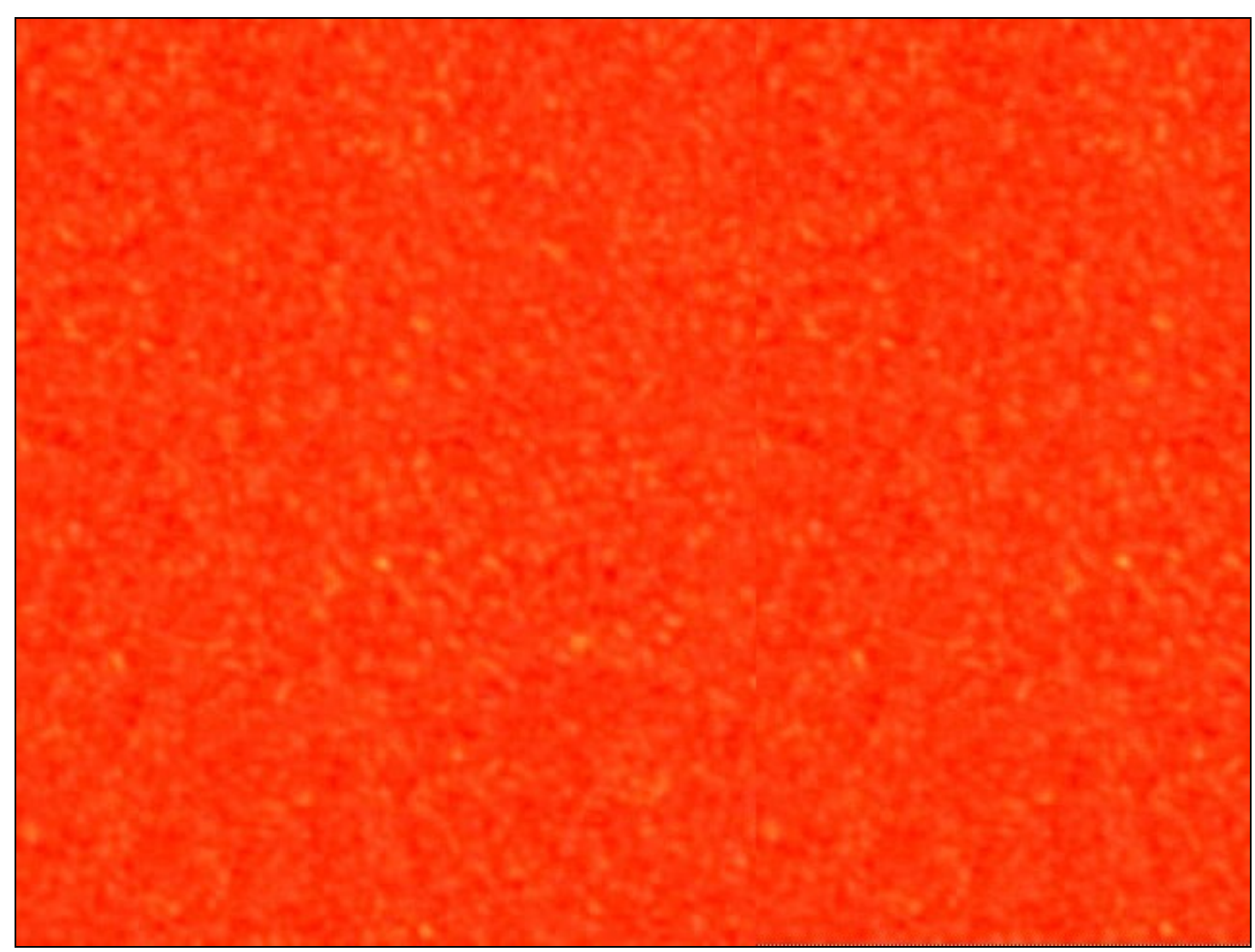

Figure 2: A frame taken from the movie recorded for the sample having a clay concentration of $3.53 \mathrm{~g} / 1$. 
The procedure presented in this article is an improvement of the procedure previously described (Chicea, 2007b), where a CMOS was used rather than a CCD. The movie recorded was a MPEG4 format and not an uncompressed AVI, which considerably reduced the amount of free space required for data saving and processing on the hard drive of the PC. The program was written in MATLAB. The recorded movie was converted to CINEPAK compression prior to processing it.

A number of 22 samples having clay suspension with different concentrations were prepared. For each sample, the cuvette was filled with the sample and an AVI type of movie lasting for 30 seconds, containing 300 frames was recorded and processed using the contrast algorithm implemented in the computer program written for this purpose (Chicea, 2007a, b).

A simple, but longer lasting procedure was also used to measure the actual amount of sediment in a sample, as an alternative and control method. It consists of weighing an empty and freshly cleaned Petri dish, of adding $50 \mathrm{ml}$ of suspension in the dish and allowing it to slowly evaporate at a temperature around $50^{\circ} \mathrm{C}$ that was controlled by adjusting the distance from the dish to a $100 \mathrm{~W}$ light bulb. After the water evaporation was completed, the dish with the sediment was weighed again. If $\mathrm{m}_{\mathrm{e}}$ states for the mass of the empty dish, $\mathrm{m}_{\mathrm{t}}$ for the mass of the dish plus sediment, then:

$$
m_{s}=m_{t}-m_{e}
$$

where $\mathrm{m}_{\mathrm{s}}$ is the mass of the sediment. The error of measuring the sediment mass with this weigh difference procedure can be estimated as:

$$
\varepsilon=\frac{2 * 0.001}{m_{s}} * 100, \quad \%
$$

where $0.001 \mathrm{~g}$ is the sensitivity of the electronic scale and $\mathrm{m}_{\mathrm{s}}$ is expressed in grams. Equation (3) reveals that the error in measuring the sediment mass by weigh difference is not constant, but increases to unreasonably high values for samples containing very small amounts of sediment.

\section{RESULTS AND DISCUSSIONS}

The samples were prepared using the procedure described in the previous section starting with a concentration of $6.6 \mathrm{~g} / \mathrm{l}$ and decreasing it by successive dilution down to 0.081 $\mathrm{g} / \mathrm{l}$. This concentration range is quite extended, as it covers two orders of magnitude. The average contrast was computed for each sample and the results are presented in figure 3 .

We notice that the average contrast presents an indefinite trend in the very small concentration range. From $0.08 \mathrm{~g} / \mathrm{l}$ to $0.35 \mathrm{~g} / \mathrm{l}$, the contrast decreases and then increases as the concentration increases up to $1.54 \mathrm{~g} / \mathrm{l}$. As the concentration increases further on up to $6.6 \mathrm{~g} / \mathrm{l}$ the contrast exhibits a monotone decreasing trend. Overall, the curve that can be plot through the data points is smooth and the error bars are small when compared to the range of the contrast $\mathrm{K}$ values.

This result is similar with the results reported by (Piederrière et al., 2004b) on latex microspheres, although at a first look (Piederrière et al., 2004a) presents an almost linear decrease. Moreover, in Piederrière et al. (2004b), the decrease for $0.2 \mu \mathrm{m}$ diameter microspheres is similar with the contrast decrease reported in this work. This can be explained by the much bigger concentration range used in this work. The work presented in Piederrière et al. (2004b) represents just a small area of the extended decreasing part of the curve in figure 3. 
If we extract the extended range where the variation is monotone, which is 1.54 to 6.6 $\mathrm{g} / \mathrm{l}$, we find the plot in figure number 4. Examining the plot of the average speckle size variation with the concentration, we notice that the curve can be used as a calibration curve for measuring the concentration in the $2-6.6 \mathrm{~g} / 1$ concentration range.

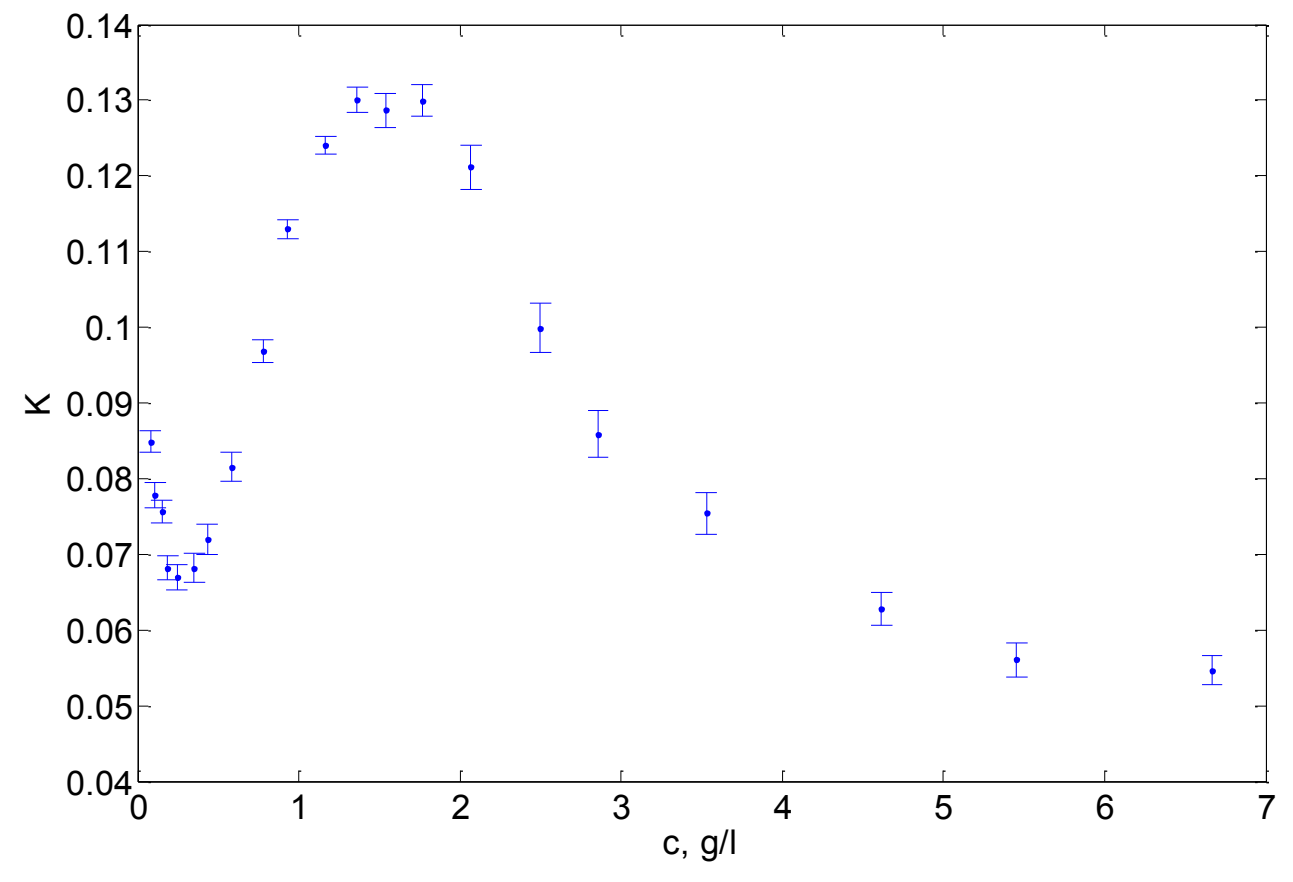

Figure 3: The average contrast versus clay concentration.

The procedure was tested for three samples with unknown clay concentration, obtained by mixing two unmeasured volumes of different diluted samples. The samples were analyzed both by the contrast and the evaporation followed by weight difference. The results are presented in table number 1 , where the first column is the clay concentration measured by the sediment mass, after evaporation, divided by the $50 \mathrm{ml}$ volume, the second column contains the concentration measured by average contrast assessment, the third column contains the error of the weight difference method, the fourth contains the error of the average contrast method, and the fifth contains the error of one method relative to the other, considering the weight method as reference.

Examining table number 1 data, we notice that the error of one method relative to the other is comparable with the sum of the relative errors of the two methods. This fact suggests that in the above mentioned concentration range the clay concentration can be assessed by the most rapid method described in the previous section. Moreover, the slope of the curve in figure number 4 is bigger in the smaller clay concentration range, which makes the speckle contrast method more precise in this range, where the weigh difference method has a lower precision, as pointed out by equation (3) and by the third column in table number 1 . 


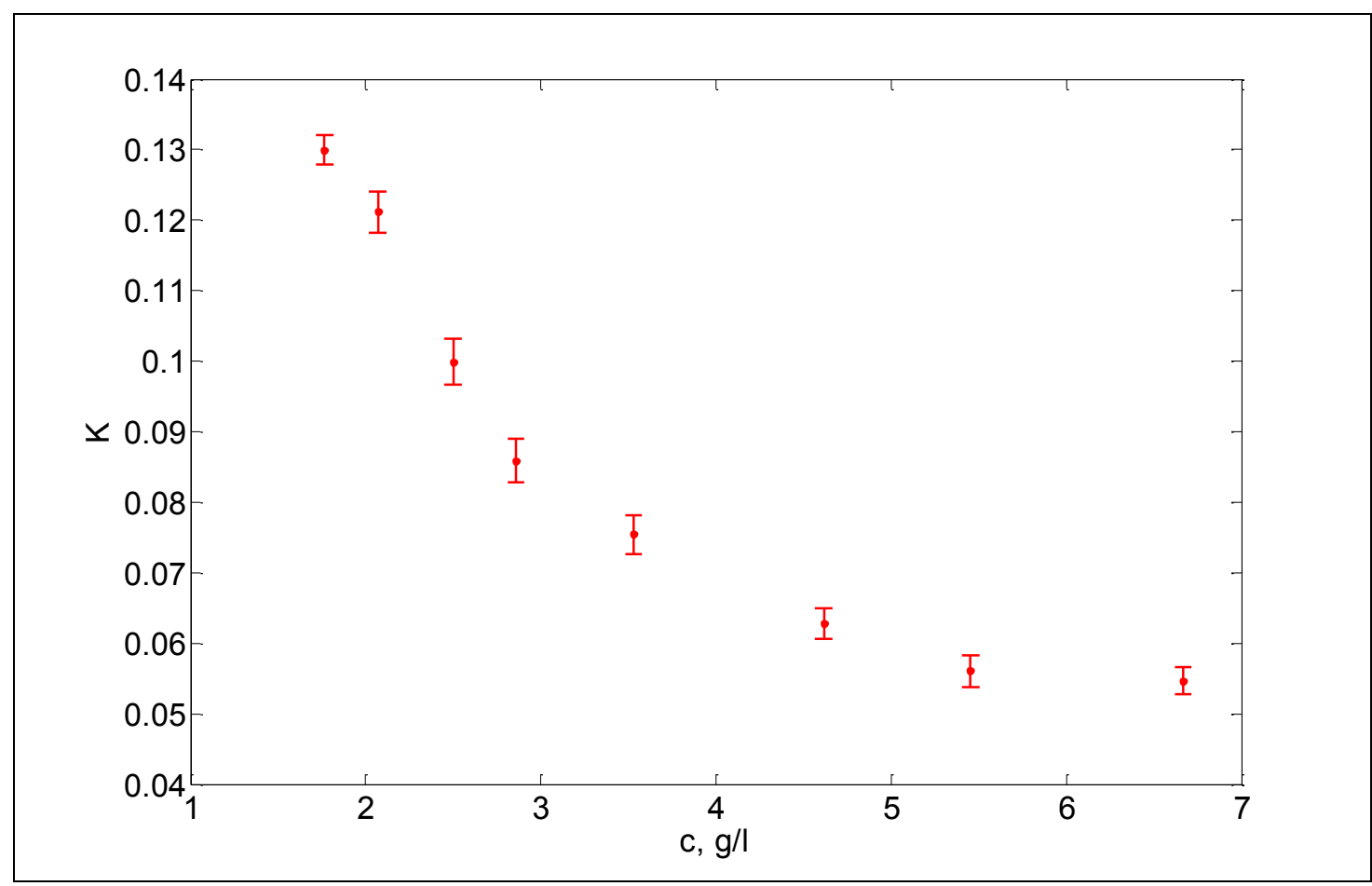

Figure 4: The average contrast versus clay concentration in the range with a monotone decreasing trend.

The procedure described in the materials and method samples resembles to a certain degree to the physical procedure previously described (Chicea, 2012c), yet it is essentially different. In Chicea (2012c), a time series is recorded using a detector and the time series is processed by averaging the scattered light intensity, while in the work described here image processing is employed.

Table 1: The three unknown samples concentration and errors in measured concentrations.

\begin{tabular}{|c|c|c|c|c|}
\hline $\begin{array}{c}\mathrm{c}, \mathrm{g} / \mathrm{l} \\
\text { weigh } \\
\text { difference }\end{array}$ & $\begin{array}{c}\mathrm{c}, \mathrm{g} / \mathrm{l} \\
\text { contrast }\end{array}$ & $\begin{array}{c}\text { Error } \\
\text { of the weigh } \\
\text { difference } \\
(\%)\end{array}$ & $\begin{array}{c}\text { Error } \\
\text { of the contrast } \\
\text { method } \\
(\%)\end{array}$ & $\begin{array}{c}\text { Error } \\
\text { between } \\
\text { methods } \\
(\%)\end{array}$ \\
\hline 2.69 & 2.57 & 1.6 & 3.3 & 4.5 \\
\hline 4.61 & 4.81 & 0.8 & 3.5 & 4.3 \\
\hline 5.79 & 5.94 & 0.7 & 3.6 & 2.6 \\
\hline
\end{tabular}




\section{CONCLUSIONS}

A simple physical procedure using the far interference field of a coherent light beam incident on a suspension can be used to assess the clay concentration in natural water over a certain concentration range. The far interference field is recorded using a CCD and the movie is processed later on. The average speckle size is computed using a program written for this purpose and an algorithm previously tested. The average contrast variation with the concentration was found to be monotone (Fig. 4) over an extended concentration range, which is from $1.54 \mathrm{~g} / 1$ to $6.6 \mathrm{~g} / \mathrm{l}$. This is a range with a relatively big concentration in natural water, as the water sample is opaque even for a $12 \mathrm{~mm}$ thick cuvette. For such a big concentration, turbidity is not measurable with the simple method using the Secchi disk (Waterwatch Australia, 2002). The monotone variation (Fig. 4) can be used as a calibration curve. An unknown sample can be used as a target for the laser beam and a movie can be recorded, the speckle size can be measured using the above mentioned procedure and the curve (Fig. 4) can be used to assess the clay concentration in that water sample.

The average contrast method has the advantage of being fast, as it does not require chemical or physical sample processing, but simply putting the sample in the cuvette, recording and processing the movie. Once the contrast is computed, finding the concentration from the plot (Fig. 4) is straightforward. A refinement might consist in fitting a polynomial on the data in figure number 4, considering the concentration versus contrast and using the polynomial for a direct calculation of the concentration from the computed contrast, which is the subject of a future work. The above mentioned steps can last less than ten minutes, once the calibration curve in figure number 4 is ready to be used. Nevertheless, a preliminary concentration assessment by sedimentation, evaporation and weighing the sediment has to be performed, in order to make sure that the concentration is in the monotone range (Fig. 4). 


\section{REFERENCES}

1. Aizu Y. and Asakura T., 1991 - Bio-speckle phenomena and their application to the evaluation of blood flow, Optical Laser Technology, 23, 205-219.

2. Berlasso R., Perez F., Quintian Rebollo M. A., Raffo C. A. and Gaggioli N. G., 2000 - Study of speckle size of light scattered from cylindrical rough surfaces, Applied Optic, 39, 5811-5819.

3. Blănaru C., Ticulean M. and Sasu G., 2008 - The structure and dynamics of the phytoplankton from Dragomirna and Solca lakes (Moldavia, Romania), Acta Oecologica Carpatica, I, 1-6.

4. Boas D. A. and Yodh A. G., 1997 - Spatially varying dynamical properties of turbid media probed with diffusing temporal light correlation, Journal of American Optical Society, 14, $192-$ 215.

5. Briers J. D., 2001 - Laser Doppler, speckle and related techniques for blood perfusion mapping and imaging, Physiological Measurement, 22, R35-R66.

6. Briers J. D., Richards G. and He X. W., 1999 - Capillary blood flow monitoring using laser speckle contrast analysis (LASCA), Journal of Biomedical Optics, 4, 164-175.

7. Chicea D., 2007a - Speckle Size, Intensity and Contrast Measurement Application in MicronSize Particle Concentration Assessment, European Physical Journal Applied Physics, 40, 305310, DOI: 10.1051/epjap:2007163.

8. Chicea D., 2007b - Biospeckle Size and Contrast Measurement Application in Particle Sizing and Concentration Assessment, Romanian Journal of Physics, 52(5-7), 581-587.

9. Chicea D., 2010 - Nanoparticles and Nanoparticle Aggregates Sizing by DLS and AFM, Journal of Optoelectronics and Advanced Materials, 4(9), 1310-1315.

10. Chicea D., 2012a - A Study of Nanoparticle Aggregation by Coherent Light Scattering, Current Nanoscience, 8(6), 259-265.

11. Chicea D., 2012b - A Coherent Light Scattering Procedure to Measure Very Small Concentration of Organic Suspension in Natural Water, Transylvanian Review of Systematical and Ecological Research, 14(2), 1-8.

12. Chicea D., 2013 - Estimating Particle Concentration in Natural Water by Speckle Size Measurement, Proceedings of 11th International Conference on Environment, Ecosystems and Development (EED '13), Braşov, Romania, June 1-3.

13. Chicea D., Indrea E. and Creţu C. M., 2012 - Assessing $\mathrm{Fe}_{3} \mathrm{O}_{4}$ Nanoparticle Size by DLS, XRD and AFM, Journal of Optoelectronics and Advanced Materials, 14(5-6), 460-466.

14. Coman A. and Sandu C., 2009 - Peculiarities of ecological evolution of Musura Bay (Danube Delta) between 2005-2007, Romanian Journal of Biology - Zoology, 54(2), 167-180.

15. da Costa G. and Ferrari J., 1997 - Anisotropic speckle patterns in the light scattered by rough cylindrical surfaces, Applied Optics, 36, 5231-5237.

16. Fedosov I. V. and Tuchin V. V., 2011 - The use of dynamic speckle field space time correlation function estimates for the direction and velocity determination of blood flow, Proceeding of Society of Photonics and Imaging Engineering (SPIE), 4434, 192-196.

17. Fulga N. and Kiseliova O., 2006 - Sexual maturation of the industrial valuable species of fish females under modified conditions of the Dubăsar water accumulation reservoir, Acta Ichtiologica Romanica I, 93-102.

18. Giglio M., Carpineti M., Vailati A. and Brogioli D., 2001 - Near-field intensity correlation of scattered light, Applied Optics, 40, 4036-4040.

19. Goodman J. W., 1984 - Statistical Properties of Laser Speckle Patterns, in Laser speckle and related phenomena, vol. 9 in series Topics in Applied Physics, Dainty J. C., Ed., SpringerVerlag, Berlin, Heidelberg, New York, Tokyo.

20. Gumpinger C., Höfler S., Berg K. and Scheder C., 2010 - Water temperature as an applicable parameter with a high indicative value for the general condition of a river-ecosystem, drawing on the example of the river Trattnach in Upper Austria, Transylvanian Review of Systematical and Ecological Research, 10 (eds Curtean-Bănăduc A. et al.), The Wetlands Diversity, 1-14. 
21. Lehmann P., 1999 - Surface-roughness measurement based on the intensity correlation function of scattered light under speckle-pattern illumination, Applied Optics, 38, 1144-1152.

22. National Soil Survey Handbook Part 618 (42-55) Soil Properties and Qualities, 2006 - United States Department of Agriculture - Natural Resource Conservation Service, May.

23. Nothdurft R. and Yao G., 2005 - Imaging obscured subsurface in homogeneity using laser speckle, Optics Express, 13(25), 10034-10039.

24. Piederrière Y., Cariou J., Guern Y., Le Jeune B., Le Brun G. and Lotrian J., 2004 - Scattering through fluids: speckle size measurement and Monte Carlo simulations close to and into the multiple scattering, Optics Express, 12, 176-188.

25. Piederrière Y., Le Meur J., Cariou J., Abgrall J. F. and Blouch M. T., 2004 - Particle aggregation monitoring by speckle size measurement; application to blood platelets aggregation, Optics Express, 12, 4596-4601.

26. Sadhwani A., Schomaker K. T., Tearney G. J. and Nishioka N. S., 1996 - Determination of Teflon thickness with laser speckle, I, Potential for burn depth diagnosis, Applied Optics, 35, 5727-5735.

27. Salem A. H. I., 2011 - Morphometric measurement and field estimation of the size of Crocodylus niloticus in lake Nasser (Egypt), Transylvanian Review of Systematical and Ecological Research - The Wetlands Diversity 12 (eds Curtean-Bănăduc A. et al.), 53-76.

28. Waterwatch Australia National Technical Manual, Module 4, 2002 - Waterwatch Australia Steering Committee, Environment Australia, July 2002, ISBN 0-6425-4856-0.

29. Zimnyakov D. A., Briers J. D. and Tuchin V. V., 2002 - Speckle technologies for monitoring and imaging of tissues and tissuelike phantoms, chapter 18 in Handbook of biomedical diagnostics, Valery V. Tuchin, Ed. SPIE press, Bellingham.

30. Zubcov N., Zubcov E. and Schlenk D., 2008 - The dynamics of metals in fish from Nistru and Prut rivers (Moldova), Transylvanian Review of Systematical and Ecological Research 6 (eds Curtean-Bănăduc A. et al.), 51-58. 